\title{
PIAS3 wt Allele
}

National Cancer Institute

\section{Source}

National Cancer Institute. PIAS3 wt Allele. NCI Thesaurus. Code C52905.

Human PIAS3 wild type allele is located in the vicinity of $1 \mathrm{q} 21$ and is approximately $11 \mathrm{~kb}$ in length. This allele, which encodes E3 SUMO-protein ligase PIAS3 protein, plays a role in both signal transducer and activator of transcription family- and steroid hormonemediated signal transduction. 